\title{
CÁRDENAS AND THE CASTE WAR THAT WASN'T: STATE POWER AND INDIGENISMO IN POST-REVOLUTIONARY YUCATÁN*
}

$\mathbf{T}$ The Caste War that devastated Yucatán in the middle of the nineteenth century cast a long shadow across ethnic relations and politics in the state decades after its effective end. During the Mexican Revolution and the subsequent period of national reconstruction, revolutionary politicians invoked the Caste War as a precursor to the Revolution and as justification for post-Revolutionary projects, in particular indigenismo. The state's indigenist policy advocated, in the words of Alan Knight, the "emancipation and integration of Mexico's exploited Indian groups." ' To this end, it offered indigenous people education, legal support, even land; however, these "modernizing" policies also destroyed or appropriated much of their culture and subordinated them to the state. ${ }^{2}$ The legacy of the Caste War shaped such indigenist projects in Yucatán from the Revolution to (at least) the 1930s, but its influence was strongest during Cardenas' visit to Yucatán in August of 1937. The president not only reinterpreted the Caste War to

* I would like to thank Gilbert M. Joseph, Terry Rugeley, Paul Sullivan, and members of Eastern Illinois University's Department of History colloquium for their comments on earlier drafts of this essay. Any errors that remain are, of course, the author's alone. In referring to archival material, the Archivo General de la Nación is abbreviated as AGN, followed by either OyC (Alvaro Obregón y Plutarco Elías Calles), AR (Abelardo Rodríguez), LC (Lázaro Cárdenas) or DGG (Dirección General de Governación), and then the number of the expediente, and, if necessary, the legajo. Material from the Archivo General del Estado de Yucatán is cited as AGEY, followed by either MA, signifying Archivo Municipal, or PE, indicating Poder Ejecutivo, followed by the seccion $(\mathrm{SG}=$ Governación, $\mathrm{SH}=$ Hacienda, and $\mathrm{SE}=$ Educación).

${ }^{1}$ Alan Knight, "Racism, Revolution, and Indigenismo: Mexico, 1910-1940" in Richard Graham, ed., The Idea of Race in Latin America, 1870-1940 (Austin: University of Texas, 1990), p. 80.

2 Julio C. Tresierra, "Mexico: Indigenous Peoples and the Nation-State," trans. Charles Robert, in Donna Lee Van Cott, ed., Indigenous Peoples and Democracy in Latin America (New York: St. Martin's Press, 1994), p. 190. 
justify land reform and a broad indigenist project; he attempted to mobilize the Yucatecan peasantry along class and ethnic lines and threatened recalcitrant landlords with another caste war should they oppose him. Once armed, however, peasant soldiers turned their rifles not against the landowners but against each other. This essays explores how the Caste War's legacy shaped the development and deployment of indigenist projects in Yucatán from the Revolution to the late 1930s, focusing on Cárdenas' aborted mobilization. Along the way, it will consider the impact and efficacy of state-sponsored indigenismo. Above all, it seeks to understand why state efforts to champion the cause of the Maya failed to unify the rural poor of Yucatán under the banner of Cardenismo.

\section{Yucatán from the Caste War to Cárdenas}

In the last decades of the nineteenth century, Yucatán recovered from the ravages of the Caste War through a new boom in export agriculture. The invention of McCormick's mechanized harvester fueled global demand for Yucatecan-grown henequen fiber as a binder, which in turn transformed the state from an economic backwater into one of Mexico's most prosperous regions. The white planter class created henequen haciendas, and used debt peonage to coerce Maya laborers into their fields. Even after federal and state troops had driven most of the Caste War rebels into sparsely populated southern and eastern parts of the peninsula (what would become the federal territory of Quintana Roo), the specter of ethnic conflict still haunted the minds of landowners during the Porfiriato.

The growth of the henequen plantation economy spread debt servitude into the Yucatecan countryside. Coming on the heels of the destruction of the Caste War, intensified capitalist penetration shattered peasant communities in northern, central, and western Yucatán. The splintering of social relationships previously centered on the village broke down collective identity. Consequently, when the Revolution began, the Maya-speaking rural poor in most of Yucatán lacked a shared, common sense of being "Maya," although the individual experience of racial inequality undoubtedly existed among peons and peasants toiling on henequen estates. Despite the breakdown of communally-based indigenous identities, the fact that capitalist production took place on rural henequen haciendas rather than in an urban environment largely preserved Maya language and other culture traits. Even as peons (rural estate workers) continued to speak Maya and celebrate folk religious festivals on the haciendas, estate owners would extend their control over them through practices traditionally a part of patron-client relationships 
such as loans (for sustenance as well as dowries) and god-parentage. ${ }^{3}$ This set Yucatán apart from most of the rest of southern and central Mexico, (like the Maya highlands of the nearby state of Chiapas) where strong communal structures survived. ${ }^{4}$

The henequen boom in Yucatán was but one regional example of the remarkable economic growth that took place across Mexico during the 34year rule of Porfirio Díaz. Porfirian prosperity, which benefited mainly foreign investors and the domestic upper class, was achieved at the cost of considerable repression and political exclusion. In 1911, liberal, middle class reformers supported by popular forces overthrew Díaz's regime in ćentral and northern Mexico. Yucatán did not escape upheaval, but the planter elite managed to weather widespread insurgencies. ${ }^{5}$

During the twilight of the Porfiriato in Yucatán, competition among elite cliques for political spoils heightened, and opposition leaders Delio Moreno Cantón and José María Pino Suárez reached out to segments of the population previously excluded from oligarchical electioneering. Mobilizations were met by repression, leading to violence. Despite their popular base and scattered, often bloody attacks against some landowners and representatives of the Porfirian order, these uprisings during the last years of the Porfiriato were far from the potential caste wars feared by some wealthy whites. They were funded, and largely organized, by patrician politicians as part of intraelite struggles. Rival elite factions which used violent uprisings to maneuver for power were in the end able to control or suppress popular mobilizations. Nevertheless, between 1911 and 1915 the plantocracy clung to power in Yucatán, amidst rising elite fears that popular insurrection might escalate into another general racial conflict. ${ }^{6}$

In the end, it was a revolution from without, not a popular revolt from below, that toppled the Porfirian regime in Yucatán. General Salvador Alvarado at the head of 6,000 soldiers brushed aside the hacendados' forces

\footnotetext{
${ }^{3}$ Piedad Peniche Rivero, "Mujeres, intercambios matrimoniales y esclavitud durante el porfiriato, 1880-1900,' in Othón Baños Ramírez, ed., Sociedad, estructura agraria y estado en Yucatán (Mérida: Universidad Autónoma de Yucatán, University of North Carolina-Chapel Hill, University of Texas-El Paso, University of Alabama, 1990); Allen Wells, Yucatán's Gilded Age: Haciendas, Henequen and International Harvester, 1860-1915 (Albuquerque: University of New Mexico, 1985), pp. 156-163, 176-179.

${ }^{4}$ On the transformation of the Yucatecan countryside during the henequen boom, see Wells, Yucatán's Gilded Age, Chapter 6.

5 Allen Wells and Gilbert M. Joseph, Summer of Discontent, Seasons of Upheaval (Stanford: Stanford University, 1996)

"Gilbert M. Joseph and Allen Wells, "Elite Politics and Rural Insurgency" in Thomas Benjamin and Mark Wasserman, eds., Provinces of the Revolution (Albuquerque: University of New Mexico, 1990).
} 
and set up a moderately reformist regime which supported the national faction led by Venustiano Carranza. Ruling as military governor from 1915 to 1917, Alvarado implemented a series of legal reforms that ended the more coercive elements of the Porfirian order, such as the near-slave condition of debt peonage. But because Alvarado needed to maintain a functioning henequen economy, he continued the efforts of his neo-Porfirian predecessors to squelch popular revolts that often had overtones (though did not contain the genesis) of a guerra de casta. ${ }^{7}$

Alvarado wanted to end the gaping social inequalities between planters and the rural poor in Yucatán. His means of saving indigenous peasants from poverty, alcoholism, and social isolation was an interventionist state to educate, morally uplift and "Mexicanize" indigenous Yucatecans. ${ }^{8}$ Ideas of maintaining Maya culture or Maya-language instruction in public schools played no role in Alvarado's project. Despite his apparent obliviousness to Yucatán's past racial conflict and the fact that his 6,000 troops squelched the popular mobilizations of the 1911-15 era, many white planters still feared that another Caste War was in the offing due to the abolition of peonage.

The revolutionary process begun by Alvarado continued after his governorship ended in 1917. To wrest elected office from the hands of the henequen barons, Alvarado had founded the Socialist Workers Party (Partido Socialista Obrero, or PSO) in 1915. The party, later known as the Socialist Party of the Southeast (Partido Socialista del Sureste, or PSS), dominated elected office in Yucatán until the 1940s. It united much of the small middle class, some progressive elements from the old landowning class, and urban workers with rural bosses (caciques) who controlled rural mobilizations. ${ }^{9}$ Even with the mediation of the party, the organization (and arming) of peasants during violent political campaigns between 1917 and 1921 would once again raise the possibility of a second caste war in the minds of many white Yucatecos. Conservative opponents of the Revolution would repeatedly charge the PSO/PSS of intentionally trying to foment another racial conflict. ${ }^{10}$

\footnotetext{
${ }^{7}$ Eric Villanueva Mukul, Henequén y haciendas en Yucatán durante El Porfiriato (Merida: Maldonaldo, 1984), pp. 135-136.

${ }^{8}$ Salvador Alvarado, La reconstrucción de México: Un mensaje a la Puebla de América, 2 vols. (Mexico City: n.p. 1919), Vol. 2, p. 16.

9 Gilbert M. Joseph, "Caciquismo and the Revolution: Carrillo Puerto in Yucatán," in David A. Brading, ed., Caudillo and Peasant in the Mexican Revolution (Cambridge: Cambridge University, 1980), pp. 193-221.

${ }^{10}$ Gilbert M. Joseph, Revolution from Without: Yucatán, Mexico, and the United States, 1880-1924, 2nd ed. (Durham N.C.: Duke University Press, 1988), pp. 116-117; Alvaro Gamboa Ricalde, Yucatán desde mil novecientos diez, 3 vols. (Mexico City: n.p., 1955), Vol. 3, pp. 88-89, 183.
} 
Counterrevolutionary planters were not reassured by the fact that the majority of the rank-and-file membership of the PSO/PSS was Mayaspeaking mestizos and indigenous peasants, despite the fact that its leadership was whiter, better educated, and more middle class. Felipe Carrillo Puerto, who displaced Alvarado as leader of the PSS, would later be identified as something of a Maya chieftain, though he lacked most markers of Mayaness (being over six feet tall and having green eyes and fair skin.) $)^{11}$ His family was far from rich yet had intermarried with some of the state's wealthiest landowners; they were thus identified as part of the white dwellers near the town square known as vecinos (literally "neighbors"). ${ }^{12}$ Carrillo Puerto's mastery of the Maya language and his efforts to defend communal land rights and improve the economic status of peasants before the Revolution had earned him the trust of the Maya around his home of Motul. ${ }^{13}$

Under the leadership of Felipe Carrillo Puerto (president of the PSO/PSS since 1917 and governor since 1922), the PSS developed an indigenist rhetoric to try to mobilize the Yucatecan peasantry. ${ }^{14}$ Like other Revolutionary-era indigenists, Carrillo Puerto and his collaborators claimed to be the protectors of Indian people and culture while at the same time advocating the mainstreaming of indigenous peoples, what Knight calls "the progressive, persuasive integration of the Indian into Mexican society." 15 But unlike Alvarado, whose answer to the "Indian problem" ignored or even negated Maya culture, Carrillo Puerto attempted to recover the glories of the Maya past and to more aggressively redress ethnic injustice in Yucatán's history. By embracing a distinctly Yucatecan indigenismo and intensifying peasant mobilizations, Carrillo Puerto would also resurrect the memory of the Caste War. In analyzing Carrillo Puerto's program, Gilbert Joseph argues that this Mayanism was an attempt to encourage ethnic pride as a means of eventually instilling class consciousness, indigenismo being merely a way-station on the road to socialism. ${ }^{16}$

Whatever his eventual aim, Carrillo Puerto made Mayanismindigenismo directed specifically at the Maya of Yucatán—a fundamental

11 Joseph, Revolution, p. 223.

${ }^{12}$ Gamboa Ricalde, Yucatán, 3, p. 32.

${ }^{13}$ Joseph, Revolution, p. 188; Guillermo Sandoval Viramontes and Jorge Mantilla Gutiérrez, Felipe Carrillo Puerto: Ensayo biografico (vida y obra) (Mérida: Universidad Autónoma de Yucatán, 1994), p. 58.

${ }^{14}$ Francisco J. Paoli and Enrique Montalvo, El socialismo olvidado de Yucatán (Mexico City: Siglo XXI, 1977), Chapters 2-6.

${ }^{15}$ Knight, "Racism," pp. 81-82.

16 Joseph, Revolution, pp. 222-223. 
part of his program as governor. And with this explicit championing of the cause of the Maya, the memory of the Caste War would no longer be repressed. Mayanist symbology developed by Felipe Carrillo Puerto and his collaborators blended Mayan iconography with Socialist and even some Christian elements. ${ }^{17}$ His Mayanist zeal extended to permitting only paintings with "Maya character" in public buildings. ${ }^{18}$ The energetic cultural campaign launched by Carrillo Puerto's government also reprinted classic texts of the pre-Conquest Maya of Guatemala, the Popul Vuh, and the Yucatesan Maya Chilam Balam. ${ }^{19}$ The keystone of Carrillo Puerto's indigenist program was the reconstruction of pre-Conquest Maya ruins, intended to remind all peninsular inhabitants of the achievements of the ancient Maya and instill pride among their descendants. ${ }^{20}$ Mayanism was not the province solely of revolutionary politicians in Yucatán. At a speech at Chichén Itzá, North American scholar John Merriman of the Carnegie Institute celebrated the hard work and enthusiasm of local workers who had labored in the reconstruction of Chichén, and pointed out that the monuments were not built by genies (apparently a common misconception of the day) but by "the Red Race." ${ }^{21}$ In a similar attempt to use past achievement of the Maya to instill ethnic identity and pride, Carrillo Puerto not only encouraged the restoration of famous sites such as Uxmal, he instructed town councils across the state to search for ruins in their localities because "they symbolize the greatness of your race."'22 Carrillo Puerto's reconstruction of Maya history extended into the more recent—and more politically sensitive-past. Maya heroes honored by the Socialist Party included Nachi Cocom, who led the sixteenth century resistance to the Spanish conquerors, Jacinto Canek, an Hispanicized Maya baker who led an eighteenth-century revolt against colonial rule, as well as the leaders of the Caste War. ${ }^{23}$ Chiefs of the remaining rebel Maya visited Mérida and pledged their support for Carrillo Puerto. ${ }^{24}$

\footnotetext{
${ }^{17}$ Details of Carrillo Puerto's Mayanist policy are drawn from Joseph, Revolution, pp. 219-222.

${ }^{18}$ Franco Savarino, "Abalá, un pueblo revolucionario," Unicornio 3:166 (20 mayo 1994), fn 74, 11 , citing a circular sent from the Central League to all municipal authorities 26 March 1923.

${ }^{19}$ The Chilam Balam was a pastiche of history, cosmology, and religious prophecy maintained by Maya communities during the colonial era. Joseph, Revolution, pp. 222-223.

20 Joseph, Revolution, pp. 222-223.

21 Tierra, 15 March 1928.

${ }^{22}$ Circular of Governor Felipe Carrillo Puerto to all municipal town councils 28 February 1923, cited in Savarino FN 74, 11.

${ }^{23}$ After the Revolution, even conservative historians looked anew at past ethnic confrontations. In November 1936, Ignacio Rubio Mañé published a study of Jacinto Canek's short-lived uprising against the colonial order, declaring it not a "mere riot" but an independence movement. Diario de Yucatán, 22 November 1936.

${ }^{24}$ Diario del Sureste, 8 April 1936; Joseph, Revolution, p. 254.
} 
The state-sponsored commemoration of the Caste War rebels as heroes, as well as attempts to mobilize Maya-speaking peasants along racial and class lines brought back fears of the Caste War among the henequen barons. Despite the anxiety of the Yucatecan upper class, the arming of Maya peasants by the PSO-PSS did not lead to another caste war. Indeed, conservative parties distributed arms to peasant followers as well, just as white landowners had armed loyal retainers in the nineteenth century. But fears of a potential racial apocalypse might well have contributed to some landowners' willingness to support a revolt by federal military officers stationed in the state. This occurred in December 1923 as part of the national rebellion headed by Adolfo de la Huerta against President Alvaro Obregón and his heir apparent, Plutarco Elías Calles. Carrillo Puerto's supporters largely failed to rally to his defense, and the governor was captured and executed on January 3, 1924.25 The last words attributed to Carrillo Puerto-_"Do not abandon my Indians" - captured indigenismo's blend of empathy and paternalism.

After the defeat of the de la Huerta revolt and the restoration of civilian rule, an internal struggle divided the Socialist Party. The national government ended it by recognizing José María Iturralde Traconis as governor. Like Carrillo Puerto, Iturralde was of (predominantly if not exclusively) European descent, and from an even wealthier family. Yet like Carrillo Puerto he was identified as a representative of the Maya. One of Iturralde's biographers even claimed Iturralde was the "white god of the Maya" of eastern Yucatán and Quintana Roo. ${ }^{26}$ As governor, Iturralde created a Corps of Maya Volunteers recruited from Kanxoc and other small villages around his home town, the eastern city of Valladolid. The discomfort caused by the presence of several hundred well-armed indigenous peasants in the state's capital among Mérida's upper crust led to the rapid disbanding of the Maya Volunteers by Iturralde's conservative successor, Alvaro Torre Díaz (192630). The Caste War, over in all but the most distant eastern reaches of the Yucatán peninsular for more than fifty years, was still lurking in the collective memory of white and mestizo Mérida; the sight of armed indigenous troops from the east in the capital brought back unpleasant memories of the conflict. ${ }^{27}$

\footnotetext{
${ }^{25}$ On the De la Huertista revolt, see Faulo M. Sánchez Novelo, La rebelión delahuertista en Yucatán (Mérida: Diario del Sureste, 1991).

${ }^{26}$ Rafael Bustillos Méndez, El Gran Kanxoc: José María Iturralde Traconis (Mexico City, Mexico: Fuentes Impresores, 1987) pp. 37, 811-83.

${ }^{27}$ Manuel Ma. Escoffie Z., Ya!: Libro de los buenos yucatecos (Mérida: n.p., 1954) p. 160; La Lucha 9 May 1931 .
} 
Torre Díaz's successor, Bartolomé García Correa (1930-33) revived Carrillo Puerto's Mayanism while skillfully manipulating the memory of the Caste War for full political advantage. Unlike his predecessors Carrillo Puerto and Iturralde, García Correa looked the part of a Maya hero. The mestizo professor's dark skin earned him the nickname "Box Pato"' (from "Box," Maya for black, and "Pato," Spanish for duck), and his enemies at times mocked his obvious Maya heritage by calling him Batab, a chieftain in pre-Columbian Mayan society. ${ }^{28}$ García Correa's Mayanism, like that of Carrillo Puerto, both paternalistically championed the indigenous peoples of Yucatán and celebrated elements of their culture, while also promising to "modernize" them by spreading Western models of labor, consumption, and recreation. In his 45 Points of Concrete Action for the Socialist Party of the Southeast, García Correa promised to "elevate the Indian to a better way of life, providing such necessities as hygienic houses, clothes, shoes, and other domestic items, while spreading sports and other diversions. "' 29 Baseball was one way in which Socialist officials tried to improve the lives of the Yucatecan peasantry. ${ }^{30}$ Other means included female beauty pageants and male contests to reward the most "hardworking" and "progressive" males; winners were crowned "India bonita" and "Indio robusto." "Modern customs" were to be spread by traveling theater companies, while movies would disseminate science. ${ }^{31}$ It was education, however, that was the most prized means of transforming the Maya. García Correa advocated scholarships to send children to Mexico City and abroad, and rural normal schools to train teachers from peasant backgrounds. Education was above all a means of spreading the Spanish language ("castillizacion"' in the words of García Correa), which would liberate the Maya from the isolation imposed by their language.

Even as he worked to spread Spanish and Western ways among the Maýa, García Correa revived Felipe Carrillo Puerto's attempts to incorporate Maya elements into public ceremonies and state-sponsored organizations- $\mathbf{a}$ contradiction that did not faze Box Pato. The Yucatecan Exploradores (Scouts) had ranks with titles taken from pre-Conquest Maya society. ${ }^{32}$ Mayanism trickled down to primary schools, where teachers instructed children in

${ }^{28}$ La Ráfaga, 14 July 1933.

${ }^{29}$ Antonio Bustillos Carrillo, Yucatán al servicio de la patria y de la Revolución (Mexico City: Casa Ramírez Editores, 1959), p. 295.

${ }^{30}$ Octavio Santos to governor 3 October 1932, AGEY PE 943 SG.

31 Tierra, May 1930.

${ }^{32}$ Gustavo González to governor 27 January 1932, AGEY PE 951 SG 
drawing that used supposedly Maya styles..$^{33}$ Just as the Bartolista administration appropriated Maya elements into official art and public ceremonies to bolster its claim to be the authentic and legitimate representative of "the Maya" in Mexico City, the regional bourgeoisie often borrowed (or simply fabricated) elements from Maya culture and incorporated them into their cultural presentations. The "brown-face" of the (mestizo and white) elite of Yucatán served to give the peninsula bourgeoisie a claim to social privilege based on comprehension of "their" Maya, an understanding that outsiders (or huaches, as they are known in Yucatán) lacked. ${ }^{34}$ Gustavo Río's opera Kinchi, which premiered September 17, 1933, featured supposedly Maya music and romanticized recreations of actual events from pre-Conquest Maya history (such as Nachi Cocom's murder of leaders of the rival Xiu tribe) ${ }^{35}$ The García Correa regime sponsored the Mexico City performance of Payambé, a similar pseudo-historical drama based on a largely invented Maya past written by white, urban authors. ${ }^{36}$

While patronizing a purely regional Mayanism, Bartolismo (as García Correa's regime was known) at times also advocated a more national indigenismo that posited a single, trans-Mexican race of Indians. The house organ of the Bartolista PSS, the monthly magazine Tierra, often celebrated the Red or Bronze Race and referred to Mexico as "Anahuac" (the Aztec name for the area embracing most (of central and southern area of the modern Mexico nation). ${ }^{37}$ The heterogenous nature of Bartolista indigenismo reflected different political agendas and a variety of intellectual influences. It combined the research of foreign investigators, the romantic race fantasies of bourgeois artists, and Social Darwinist ideas of race which were deeply ingrained in society from the mid-nineteenth century on. ${ }^{38}$ Moreover, political considerations often affected the eclectic indigenismo of the early 1930s. This was perhaps most apparent in García Correa's interpretation of the Guerra de Castas, a compelling but potentially dangerous indigenist theme.

${ }^{33}$ Antonio Betancourt Pérez to Professor Bartolomé García Correa 12 August 1932, AGEY PE 952 SG 2.

${ }^{34}$ On how regional bourgeoisie integrate elements of indigenous culture into their own, see Claudio Lomnitz-Adler, Exits from the Labyrinth: Culture and Ideology in the Mexican National Space (Berkeley: University of California, 1992), Chapters 1, 10 and 11.

${ }^{35}$ Heraldo de Yucatán, 30 December 1933.

${ }^{36}$ Bartolomé García Correa, Como se hizo su campaña política (Mérida: Imprenta Gamboa Guzmán, 1930), pp. 257-275.

${ }^{37}$ Based on a review of numerous issues of Tierra from 1928 to 1931.

${ }^{38}$ Knight, "Racism," p. 77. 
Bartolista references to the Caste War reflected contradictory attempts to restore pride to the indigenous peoples of Yucatán and at the same time to use the memory of the conflict to justify the PSS's domination of state politics. Tierra published an article shortly after García Correa's inauguration which rejected the traditional view espoused by Yucatán's white elite that the war was a struggle between civilization and barbarism. It argued instead that the Caste War was a tragedy caused by the rich's exploitation of the poor. ${ }^{39}$ Although the Bartolista official discourse portrayed the Caste War as a just uprising against oppression, García Correa and his collaborators also used the traditional view of the Caste War as a revolt of semibarbaric Mayas against (white) civilization to forward their own interests in dealings with national elites. During his campaign for governor, García Correa boasted to Mexico City reporters that he would provide "discipline to nourish the idiosyncrasies of the brown multitudes," implying that his administration would prevent another racial conflict. ${ }^{40}$ In private, Socialist Party officials issued dire warnings about the possibility of racial conflict; in 1932, a high official of the PSS told American researcher Ruth Clark that peasants must be kept pacified by García Correa's administration because they were "imperfectly civilized" and capable of revolting. ${ }^{41}$ García Correa's attempts to centralize political power on a regional level could be justified to national authorities on the grounds that it kept "the Maya" under control and thus prevented another caste war. Ironically, despite Box Pato's calls to spread Spanish fluency as part of the modernization of Yucatán, the power of García Correa's Socialist Party depended on the continuing Maya monolingualism of the "brown multitudes." A federal official sent from Mexico City to observe the senatorial election of 1926 in Yucatán noted that the outcome was virtually predetermined by the Socialist Party. He attributed the party's dominance of local and national elections for years on end to the fact the local authorities and citizens understood very little Spanish, making the PSS the sole intermediary between them and the national government. ${ }^{42}$

Not all observers traced the PSS's electoral hegemony to its ability to mediate linguistically and culturally between the Maya and Mexico City. Opponents charged Box Pato with using his Revolutionary Guard (Defensa Revolucionaria) to silence opponents through violence and intimidation. ${ }^{43}$

\footnotetext{
39 Tierra, July 1930.

${ }^{40}$ García Correa, Como se hizo su campaña política, pp. 217-218.

${ }^{41}$ Ruth Clark, Organized Labor in Mexico, 2nd ed. (New York: Russel \& Russel, 1978) pp. 212-213.

${ }^{42}$ R.M. Endisábal to Interior Secretary 26 June 1926, AGN DGG 2.311 DS (6-4).

${ }^{43}$ While head of the Socialist Party during the administration of Alvaro Torre Díaz, García Correa
} 
García Correa explained the creation of the Defensa by arguing that the death of Felipe Carrillo Puerto justified arming peasants to stave off future counter-revolutions. ${ }^{44}$ Significantly, the Guard was never an overtly indigenist instrument; it was recruited not from Maya-speaking communities of the east as were Iturralde's Maya Volunteers, but from local chapters of the Socialist Party from across the state, especially from those in Mérida. ${ }^{45}$ Quite possibly the absence of racial overtones in the raising of the Revolutionary Guard reflected a decision by García Correa to avoid fomenting fears of another ethnic conflict in Yucatán.

García Correa created the Revolutionary Guard to support his regime, yet its action helped destroy it. In April 1933, he ordered units of the Revolutionary Guard, federal troops, and state police to disarm the local Guard chapter of the small western village of Opichén because it was supporting an opposition candidate in the upcoming gubernatorial election. During a firefight among Guard members, at least 38 male peasants (and reportedly more women and children) were killed. ${ }^{46}$ In the wake of the scandal which was widely reported across Mexico, García Correa was forced to take a leave of absence and was later criticized by supporters of the incoming president, Lázaro Cárdenas. ${ }^{47}$

\section{Cardenismo in Yucatán: The Crusade of the Mayab}

Soon after taking office, President Lázaro Cárdenas (1934-1940) declared his commitment to the breakup of Yucatán's henequen haciendas and the transfer of most of their land to collectively-farmed ejidos. This provoked the Yucatecan hacendados to mobilize a coalition of loyal peons and urban workers to overthrow two governors (César Alayola Barrera in June 1935, Fernando López Cárdenas in July 1936) in order to destabilize the state politically and force Cárdenas to scrap his planned agrarian reform. ${ }^{48} \mathrm{Re}$ -

created the Defensa Revolucionario in 1927. The Guard was originally affiliated with the national League of Revolutionary Defense (Liga de Defensa Revolucionaria), a national organization founded by supporters of Alvaro Obregón as part of a defense of the Revolution against "reactionaries." Liga de "Defensa Revolucionaria de Yucatán." Reglamento (Mérida: n.p., 1927); Alfredo Pérez to President Cárdenas, AGN DGG 2.316 vol. 5; Rubén Darío Domínguez et al. to President Cárdenas 2 January 1933, AGN AR 525.25/95; Diario del Sureste 25 April 1933.

44 Timothy J. Henderson, “Unraveling Revolution: Yucatán, 1924-1930,' (M.A. Thesis, University of Texas, 1988), pp. 164-165.

${ }^{45}$ Based on numerous archival and periodical sources on local chapters of the Defensa.

${ }^{46}$ Diario del Sureste 16-21 April 1933; AGN AR 524/299.

${ }^{47}$ Partido Nacional Revolucionario, Memoria de la segunda Convención Nacional Ordinaria del Partido Nacional Revolucionario (Mexico City: Partido Nacional Revolucionario, 1933), pp. 111-112.

${ }^{48}$ José Luis Sierra Villareal and José Antonio Paoli Bolio, Cárdenas y el reparto de los henequenales (Mérida: Gobierno del Estado, 1986), pp. 43-46. 
lations between state and national governments reached a critical point in mid-1937 when Interim Governor Florencio Palomo Valencia declared a "truce" in agrarian reform. This latest reversal of the long-delayed process led Cárdenas to travel to the Yucatecan peninsula in August of 1937 to restart land reform.

Cárdenas' visit, dubbed "the Crusade of the Mayab" (land of the Maya), attempted to mobilize the Yucatecan peasantry via land reform and indigenismo. In the process of creating ejidos, Cárdenas and his collaborators staged massive public ceremonies and travelled to dozens of towns and villages across the Yucatecan countryside. His whirlwind tour aimed not only to publicize his actions, but also to articulate the Cardenista vision of a new rural society. ${ }^{49}$ The centerpiece of the Crusade of the Mayab was Cárdenas' announcement on August third of his "Solución Salvadora" (Redeeming Solution) for Yucatán's "Agrarian Problem": nothing less than the total execution of all pending land grants in the henequen zone. ${ }^{50}$ The federal government also offered aid for new and existing ejidos, including investments in education, public health and rural infrastructure. ${ }^{51}$ Despite his sweeping promises, Cárdenas' solution to Yucatán's agrarian problem left more than 10,000 peasants and peons without land (out of a total population of some 60,000 ). In the coming months, it would be painfully apparent that most of the newly created ejidos suffered from a lack of land, a poor ratio of fallow-to-planted land, and too little access to processing machinery for their harvest. ${ }^{52}$ The economic shortcomings of the ejido system explain in part why Cardenismo failed to mobilize a popular base. Peasants and peons exchanged dependency on low wages on private haciendas for dependency on even lower "advances" on federally-controlled ejidos. The Cardenista Crusade's structural transformation of Yucatán failed

\footnotetext{
49 On parallels between religious missionaries and the Cardenistas see Marjorie Becker, Setting the Virgin on Fire (Berkeley: University of California, 1995), Chapter 4. On the importance of ceremonies in the post-Revolutionary state formation project, see Mary Kay Vaughan, "The Construction of the Patriotic Festival in Tecamachalco Puebla, 1900-1946," in William H. Beezley, Cheryl English Martin, and William E. French, eds., Rituals of Rule, Rituals of Resistance: Public Celebrations and Popular Culture in Mexico (Wilmington, DE: Scholarly Resources, 1994).

${ }^{50}$ Partido Nacional Revolucionario, La reforma agraria en Yucatán (Mexico City: Talleres de " El Nacional," 1937), pp. 1, 35.

${ }^{51}$ Diario del Sureste, 9 August 1937; Humberto Canto Echeverría, "Estudio Sobre la Situación Real de los Ejidos Henequeneros de Yucatán," 31 July 1939, AGN LC 404.1/12 caja 201 leg. 2.; Partido Nacional Revolucionario, Reforma; Humberto Lara y Lara, Sobre la trayectoria de la reforma agraria en Yucatán (Mérida: Zamna, 1949), pp. 27-28.

${ }^{52}$ Diario del Sureste 29 December 1937; Carlos M. Peralta, "Apuntes asunto de Yucatán: Introducción. Algunos antecedentes," 9 September 1939, AGN LC 404.1/12 caja 201 leg. 9; Humberto Canto Echeverría, "Estudio Sobre la Situación Real de los Ejidos Henequeneros de Yucatán," 31 July 1939, AGN LC 404.1/12 caja 201 leg. 2.
} 
to create a new class of loyal ejidatarios (recipients of collective federal land grants), and it encountered serious difficulties in attempting to mobilize Yucatecan peasants along ethnic lines.

Like previous regional projects, the Cardenista national project looked to indigenism to legitimize political aims. Perhaps influenced by Carrillo $\mathrm{Pu}-$ erto's legacy (the president was frequently advised on regional affairs by Felipe's brother Gualberto), Cárdenas heartily believed the Maya were not inherently inferior. In fact, Cárdenas, like Carrillo Puerto, subscribed to a kind of reverse racism that ascribed certain superior characteristics to indigenous peoples. ${ }^{53}$ The president claimed Yucatecan peasants "preserved the traits of their ancient and advanced civilization, as proved by their laboriousness, their cleanliness, and their respect for life." ${ }_{54}$ Like García Correa, Cárdenas hoped that indigenous people could be redeemed and their innate racial virtues cultivated for the good of Mexico. ${ }^{55}$ For both García Correa and Cárdenas, education was the preferred means of redeeming and modernizing the Maya, although Cárdenas added land reform to the formula for redemption. The Crusade was replete with ceremonial demonstrations of how indigenous people would be saved by the state through schooling, sports, and the ejido. ${ }^{56}$

Like most previous revolutionary projects that drew on indigenismo, Cárdenas' included the Caste War in public discourse. However, his references to the Guerra de Castas were not only more direct than those of previous politicos, they also interpreted it in an innovative manner: the Caste War served to couple agrarian reform with indigenismo. In announcing the transfer of land from haciendas to ejidos, Cárdenas declared that "today 90 years after the beginning of the ultimate tragedy of the Maya Race comes the Revolution to give them the henequen fields as minimal compensation for [the Indians'] blood spilled in their struggles for possession of the land."'57 Cárdenas also unified socialism and indigenism in his proclamation, setting out to collectivize henequen haciendas for reasons of social justice (land to those who worked it) and racial justice (land to those whose ancestors had lost it).

\footnotetext{
${ }^{53}$ Knight, “Racism," pp. 87, 95.

54 Fernando Benítez, Kí: El drama de un pueblo y una planta (Mexico City: Fondo de Cultura Económica, 1956), p. 233.

\$5 See Knight, "Racism," p. 87, and Becker, chapter 4, for different perspectives on the supposedly innate racial characteristics ascribed to indigenous peoples, and beliefs about their "redeemability."

${ }^{56}$ See, for instance, the account of Cárdenas' visit to Yotholín in Diario de Yucatán, 22 August 1937.

${ }^{57}$ Diario de Yucatán, 4 August 1937; Gobierno del Estado, El Ejido en Yucatán (Mérida: Ediciones del gobierno del estado, 1937).
} 
In the process of leading his crusade, the Cárdenas would rewrite the Caste War. ${ }^{58}$ While land seizures by whites undoubtedly were among the causes of the Maya uprising of 1847, the Cardenista interpretation of the Caste War omitted the strong regionalist and millennial elements of the revolt. Cardenista discourse generally referred to the Maya fighters of 1847 as Indians - not as Maya, much less Cruzo' ob (in Maya 'the People of the Cross"), the rebels own name for themselves. While Cárdenas styled land reform as historical justice, a cynical landowner might well have asked why he gave land to the peasants of the northern part of the peninsula when most of the Maya of that region had actually allied with the whites against the rebels from the south and east.

Despite Cárdenas' historical omissions in his invocation of the Caste War, his reference to the conflict served to elicit landlord cooperation by acting as a thinly veiled threat, a process examined below. Cárdenas' interpretation of the Caste War also illuminated a specific feature of the larger Cardenista program of indigenismo: an attempt to subsume indigenous peoplesregardless of specific ethnic characteristics-into a single category of "Indian." The Cardenista idea of Indianness and his nationalism demanded an interpretation of the Caste War that downplayed the separatist and specifically Maya nature of the revolt. ${ }^{59}$ The creation of a strong Mexican national identity based on pan-Mexican Indianness was especially important in $\mathrm{Yu}$ catán, an area with marked secessionist tendencies. Accordingly, Cardenista discourse restyled the Maya as generic, rather idealized, Indians, even as it linked indigenismo with land reform. ${ }^{60}$ Speaking to Mexican journalist Fernando Benítez almost two decades after the Crusade, Cárdenas continued to ignore the separatist, religious, and ethnic nature of the conflict, stating that "the so-called Caste War was nothing more than a peasant rebellion caused by the maltreatment they received and the misery in which they lived."'61 At times the economic determinism of many Cardenistas in $\mathrm{Yu}$ catán led them to consider the Caste War as just a class conflict without

\footnotetext{
${ }^{58}$ For a reexamination of the actual historical origins of the Caste War, see Terry Rugeley, Yucatán's Maya Peasantry and the Origins of the Caste War, 1800-1847 (Austin: University of Texas Press, 1996).

${ }^{59}$ The idea of a single, all-encompassing "Indian" identity had been anticipated by Porfirio Díaz when he erected a statue of Cuauhtémoc, the last Aztec emperor, in Mexico City. Díaz's project, however, was strictly for elite consumption, while Cárdenas' was not only directed at a broader audience, it also implied positive actions on the part of the national state to aid indigenous minoritiesfundamental characteristics that Porfirian proto-indigenism definitely lacked. Knight "Racism," p. 79.

${ }^{60}$ For a discussion of how Cardenismo attempted to reformulate ethnic and class identities from above in a region very different from Yucatán, Michoacán, see Becker, "Black and White and Color: Cardenismo and the Search for a Campesino Ideology," Comparative Studies in Society and History 29 (1987), pp. 453-465.

${ }^{61}$ Benítez, p. 231.
} 
ethnic dimensions; the Young Guard, a leftist, pro-Cárdenas magazine published an article entitled "Caste War: a Class Struggle" that advanced this argument. ${ }^{62}$

To be sure, Cardenas' use of the memory of the Caste War, like his use of indigenism in general, was not always ideologically coherent or consistent. He raised the possibility of a Maya revolt like that of 1847 to threaten landowners, but at the same time lumped the Maya into a generic Indian identity. Cárdenas was genuinely concerned about the condition of Mexico's indigenous peoples, but was not an ethnographer. As a politician with an imperfect understanding of Yucatán's past and present, he faced circumstances that forced him to pursue a variety of political and rhetorical strategies, which in turn led him to represent the Maya and their history in contradictory ways. The public ceremonies staged by state and federal officials provide further insight into the heterogenous nature of Cardenista indigenist and agrarian ideology.

After the proclamation of agrarian reform in Mérida, Cárdenas and his entourage moved south to the hacienda Temozón to stage a ceremony August eighth. The Cardenista magazine Menzay ("labor" in Maya) claimed it symbolized the struggle for land across the state. ${ }^{63}$ Officials supposedly chose Temozón because it was the site of an ambush in January of that year in which two young peasants affiliated with a Communist syndicate were killed. ${ }^{64}$ The land was thus hallowed by blood shed by the slain young peasants, Mena and Sosa, who were now declared agrarian martyrs. The agrarian fiesta at Temozón consisted of an elaborately planned celebration that dragged on for hours under a blazing August sun. ${ }^{65}$ Before Cárdenas proclaimed the transfer of Temozón's land from owner Humberto Peón Suárez to former peons, a series of peasant speakers who represented all of Yucatán's peasants engaged in a symbolic dialogue with their secular messiah. ${ }^{66}$ One unidentified Maya speaker at Temozón was photographed addressing the president, and the caption in Menzay read "the Mayas have not opened their mouths to explain their situation in a long time." 67 Significantly, among the demands voiced by the supposedly long-quiescent peas-

${ }^{62}$ Joven Guardia August 1937.

${ }^{63}$ Menzay unnumbered special edition issued: September 1937.

${ }^{64}$ Diario del Sureste 22 January 1937. On other motives that lay behind the choice of Temozón to begin land reform during Cárdenas' Crusade, see Ben Fallaw, "Florencio Palomo Valencia, Temozón, y la cuestión agraria en Yucatán: Cardenismo comprometido," forthcoming in Unicornio.

${ }^{65}$ Diario de Yucatan, 23 August 1937; Aldo Baroni, Yucatán (Mexico City: Ediciones Botas, 1938), pp. 106-110.

${ }^{66}$ On the importance of redemption in Cardenista ideology, see Becker, Setting, pp. 104-105.

${ }^{67}$ Menzay, September 1937 4-5. 
ants was a request for them to be armed - a suggestion warmly applauded by the crowd that probably underscored the possibility of another caste war to hacendados. ${ }^{68}$ Peasants who were to receive land then demonstrated the numerous stages in the cultivation and processing of henequen that began with the clearing of land and ended with the packing of the fiber. Such a presentation of industrial choreography not only displayed the disciplined skills of Yucatán's rural workers, it served to answer landowners' doubts that peasants were unable to cultivate henequen without their guidance. Later, members of the newly-created ejidos of Temozón and surrounding areas paraded along with federal soldiers and their uniformed wives before hundreds of bussed-in peasants waving small red pennants emblazoned with the phrase "Agrario" ("Land Reform") and a scythe (a symbolic reference to the peasants taken from Communist iconography). The ejido also received a federal school named for the "martyrs" Mena and Sosa from Cárdenas. Sports, another important part of Cardenista social reform, was present in the form of games between the baseball and basketball teams of ejidatarios and the federal Agrarian Department. Like the parade, these games allowed peasants and federal agents to share public space, implying equality.

Other public ceremonies during the Crusade of the Mayab reinforced the themes of indigenismo and agrarian reform, and sketched the new rural society envisioned by the Cardenistas; the reality of life on the ejidos was often fundamentally different. Although the dialogue between Cárdenas and peasants as well as the games and marches uniting bureaucrats and ejidatarios suggested egalitarianism, the day-to-day operations of the collective land grants demonstrated to the ejidatarios that federal officials were definitely in charge. ${ }^{69}$ Not only were indigenous people subordinated in the new Cardenista order; representatives of the state or urban, mestizo society often appropriated elements of Maya culture. At a festival staged for the visiting president at the beginning of the Crusade, regional political officials presented a series of songs and dances representing a highly stylized Maya culture. First, two men identified as spokesmen of the workers and peasants addressed the crowd-the latter was actually a career politician booed by many in attendance. Then, students and workers performed versions of peasant dances ("A la Vaquería" and others). Next, students from Mérida performed the "Dance of the Maidens and Warriors" from the Bartolistaera opera Kinchi, a performance supposedly based on pre-Conquest dances.

${ }^{68}$ Diario de Yucatán, 23 August 1937.

${ }^{69}$ Ben Fallaw, "Peasants, Caciques and Camarillas: Rural Politics and State Formation in Yucatan, 1924-1940" (Ph.D. Diss., University of Chicago, 1995), pp. 208-230. 
In all these acts, students and workers represented-or, more accurately, impersonated-Maya peasants and members of an imagined pre-Conquest Yucatán for the benefit of the president. ${ }^{70}$

Cárdenas departed the peninsula before Independence Day (16 September), but in his absence Gabino Vázquez, Secretary of the federal Agrarian Department, presided over a ceremony that capped the Crusade of the Mayab: the dedication of the just-completed Ejidal Stadium of Izamal. The ceremony and the building itself showcased Cardenista ideas linking sports, agrarian reform and indigenismo through architecture, rhetoric, and public ceremony. The stadium's location had great historical significance. Izamal was noted both for the grandeur of its huge but still unexcavated Maya ruins, and for the strength of its conservative and religious sentiment. ${ }^{11}$ In March 1922, Governor Felipe Carrillo Puerto supported the town council of Izamal's decision to take over the convent to house a rationalist school, much to the outrage of the faithful of Izamal. ${ }^{72}$ Masons and Catholics had feuded there during the height of Callista anticlericalism in the late 1920s, and a riot between the two nearly ruined a visit by then-candidate Cárdenas in 1934.73 While religion had dominated Izamal's past, the agrarian faction that emerged in 1936 controlled Izamal at the time of the Crusade-a historical transformation marked by the transfer of Izamal's convent to the ejido. ${ }^{74}$

The stadium's architecture expressed Cardenista ideology. Built around an ex-religious building, it mutely preached the triumph of the secular state over the Church. Moreover, because the convent had previously been con-

\footnotetext{
${ }^{70}$ Diario de Yucatán, 6, 7 August 1937.

${ }^{71}$ Izamal's conservative, Catholic reputation was probably due to the fact that it was the home of a large convent and impressive colonial church, and was the staging ground of the conservative revolt that toppled a Jacobin liberal governor during the Reform. Hernán Menéndez, "El liberalismo en Yucatán: De la Reforma al Imperio," Unicornio (25 April 1993): 3-11.

72 AGN OyC 438-Y-2. Rationalist schools were founded during the Socialist administration of Carrillo Puerto on the model of Spanish anarchist educator Francisco Ferrer Guardia. See Carlos Martínez Assad, ed., Los lunes rojos: La educación racionalista en México (Mexico City: Consejo Nacional de Fomento Educativo, Ediciones El Caballito, Secretaría Educación Publica, 1986); and Mary Kay Vaughan, "Education and Class in the Mexican Revolution," Latin American Perspectives 2:2 (Summer 1975), 17.

${ }^{73}$ The subject of anticlericalism lies beyond the scope of this essay. As Alan Knight has noted, the sociology of Jacobinism in the Mexican Revolution remains to be written. Alan Knight, "Popular Culture and the Revolutionary State in Mexico, 1910-1940,' Hispanic American Historical Review 74:3 (1994) fn 123, 418. However, an important regional study of anticlericalism (focusing on the state of Sonora) has been written. See Adrian Bantjes, "Burning Saints, Molding Minds: Iconoclasm, Civic Ritual, and the Failed Cultural Revolution," in Beezley, Martin, and French, eds., Rituals of Rule.

${ }^{74}$ Diario del Sureste 12 September 1937. In municipal elections in the fall of 1936, the agrarista faction (supported by the federal Agrarian Bank) had seized local power from the Socialist Party faction that had long dominated town hall with the support of the state government.
} 
structed on top of Maya ruins, the stadium physically anchored the Cardenista present to the Maya past. At the same time, the stadium obscured public space associated with the old regime (the convent, a relic of colonialism) and created a new ceremonial space dedicated to sports intended to inculcate the new values of the post-Revolutionary state. ${ }^{75}$ In erecting a forum for sports and secular ceremonies, the Cardenistas posited a new division of time through national festivals and new forms of leisure to be practiced there. ${ }^{76}$ Symbols of the Cardenista national state adorned the interior: a portrait of Cárdenas gazed down over everyone entering the stadium. Beside it was the shield of the national Agrarian Department. ${ }^{77}$ A plaque above the entry spelled out the building's relation to indigenism and agrarian reform: "Above these ruins that were the grand constructions of our ancestors, we raise this ejidal stadium where strong men and future generations of ejidatarios will be forged." Slogans emblazoned on the walls of the stadium stressed themes such as popular support for Cardenismo ("All for Cárdenas . . . to victory or death"), the link between sports, masculinity and citizenship ("Clean bodies, Strong men'), and the importance of the ejido to the nation's economic health ("The mass of peasants will rise again and increase the economy of Yucatán"'). ${ }^{78}$

Gabino Vázquez, who often represented Cárdenas in the state, personally oversaw the stadium's opening ceremonies on Independence Day. Vázquez said (through a Spanish-Maya translator) that the president wished he could be here "because the Maya race has here its strongest force and its independence." 79 His speech reminded peasants of land reform taking place elsewhere and advocated sports to strengthen the ejidatarios. After a procession of soldiers, ejidatarios, and students from the Federal High School bearing the national and agrarian flags paraded, a flame symbolizing the liberation of the peasants was lit, adding a touch of Olympic majesty:80 Finally, Vázquez presented a corn-grinding nixtamal mill to the women of Izamal, installing it in the same building that was used as an arsenal by the

\footnotetext{
${ }^{75}$ Mona Ozouf described a similar process of secularization of public space. See Festivals and the French Revolution (Cambridge: Harvard University Press, 1988), trans. Alan Sheridan, Chapter 6.

${ }^{76}$ For a comparative perspective on the importance of time in French revolutionary festivals, see Ozouf, Chapter 7.

${ }^{77}$ Pictures of the stadium were featured prominently in Menzay, unnumbered special edition published September 1937.

${ }^{78}$ Diario de Yucatán 17 September 1937.

${ }^{79}$ Unnumbered special edition of Menzay issued in September 1937.

80 The Classic Maya and Classical European ages were further conflated in February of 1939 when the state government held a peninsular games in Mérida. It featured athletes dressed in supposedly Maya costume that looked suspiciously like Olympian garb. Diario del Sureste 1 February 1939, 4 February 1939.
} 
Agrarian Militia, which in turn was adjacent to a children's park; the arrangment symbolically unified men, women and children under the state's benevolent authority. ${ }^{81}$

Ceremonies accompanying the opening of Izamal's stadium, like those for the announcement of land reform, acted as blueprints of sorts for the Cardenista vision of rural society. The corporatist structure drafted by the Cardenistas would integrate indigenous peasants directly into the state and eliminate both the old landed elite and the caciques as intermediaries. Indigenismo, agrarian reform, and sports lauded at Izamal were all means to the political end of strengthening the national state and directly incorporating the popular classes into it.

\section{The Caste War That Wasn't: Peasant Militias and Local VIOLENCE}

Cardenista indigenist rhetoric and symbology wove together diverse elements of the archaeological record with imagined (at times quite fanciful) recreations of the Maya past. Moreover, Cardenista ceremonies suggested that though the great ancient Maya civilization had long since vanished, the modern Maya could regain their dignity - with state help. But the public remembrance of the Caste War in Cardenista discourse also presented another image of the Maya, that of an oppressed group capable of rising up and taking vengeance against its tormentors. Cárdenas' invocation of the Caste War in his proclamation of land reform raised the possibility of another racial conflict should landowners not comply with Cardenista agrarian reform. In an interview with the state's largest hacendados shortly after the proclamation of his redeeming solution, Cárdenas reminded them that if their estates were not divided up and land given to the peasantry, the possibility of an armed uprising against injustice remained. ${ }^{82}$ His implication that resistance to land reform risked another caste war was made explicit and public in the Cardenista magazine Young Guard, which reprinted the president's warning that the failure to execute the long-delayed land reform "would leave the future potential of a local armed movement raising the agrarian flag against the maintenance of an unjust situation." 83 The probability of another caste war had already been increased by the creation of the Agrarian Militia in late 1936. However, a closer examination of the peasant militia's operations in Yucatán not only reveals that Cárdenas' threat of

${ }^{81}$ Diario de Yucatân, 17 September 1937.

${ }^{82}$ Diario del Sureste, 7 August 1937.

${ }^{83}$ Joven Guardia, August 1937. 
second Caste War was a hollow bluff, but also sheds more light on the difficulties the Cardenistas encountered in attempting to mobilize peasants along class and ethnic lines.

Fears that the upper class and conservative elements in the Army might mount a coup against him led Cárdenas to authorize the formation of a national peasant militia of 70,000 members known as the Agrarian Reserve in October of 1936, almost a year before his visit to Yucatán. ${ }^{84}$ Presidential advisors believed that arming and training peasants would allow them to protect their land grants, and to serve as leverage against recalcitrant landowners. ${ }^{85}$ Anxious to avoid strengthening regional warlords or antagonizing the generals, Cárdenas required that the citizen soldiers of his Agrarian Reserve be placed under the regular army's command structure and led by professional military officers. ${ }^{86}$ Membership in the national peasant militia would be limited to peasants under 40 years of age who had already received the right to land. At the time of the creation of the Agrarian Reserve, there already was a standing force of several hundred Yucatecos under the banner of the old Bartolista Revolutionary Guard. ${ }^{87}$ Federal officials refused to recognize this force as the Agrarian Militia because of its association with the massacre of Opichén in 1933. To build a peasant militia from scratch, federales took between 500 and 600 hundred Yucatecan ejidatarios to Mérida in November of 1936, where they received rifles and some rudimentary military training. ${ }^{88}$ Afterwards, squads and platoons of the peasant reserves were stationed in their home villages across the henequen zone.

The Agrarian Reserves did not suffer from a lack volunteers; peasants did

${ }^{84}$ Ann L. Craig, The First Agraristas. An Oral History of a Mexican Agrarian Reform Movement (Berkeley: University of California Press, 1983), pp. 130-131. Cárdenas' announcement of the militarization of ejidatarios sparked demands from other sectors to be armed. Teachers in Mexico City asked that male teachers receive military training, and that female teachers be trained as military nurses in order to combat enemies of socialist education. The national Confederación General de Trabajadores (CGT) requested that urban workers be armed in order to combat extremists on the right and left. The cordage factory workers of Yucatán took advantage of Cárdenas' presence to ask that workers be armed like the peasants. Cárdenas refused petitions to arm urban workers or government employees, and the closest that the cordage workers got to military training was a drum and bugle corps. Diario de Yucatán, 12 November 1936, 29 October 1936; Pedro Echeverría V., Los cordeleros, 1933-1980 (Mérida: Sindicato de Cordeleros de Yucatán and Universidad Autónoma de Yucatán, 1981), p. 103.

${ }^{85}$ Francisco Mújica, "Memorandum sobre la situación de Yucatán" 23 July 1936, AGN LC 404.1/12 leg. 2.

${ }^{86}$ Diario del Sureste, 11 October 1936.

${ }^{87}$ Benigno Pinzón to Governor Palomo Valencia 12 October 1936, AGEY PE 1018.

${ }^{88}$ Diario de Yucatán, 26 November 1936, Diario del Sureste 25 January 1938. 
not evade service in it as they sought to avoid the leva (draft) into the regular army. ${ }^{89}$ In fact, upwardly-mobile rural Yucatecans who had already held civilian office or built up a small clientele used military posts to advance their own political careers or to consolidate their hold over local power. Federal officials were well aware of the potentially destabilizing effect that the creation of peasant militias could have on local politics; the Ministry of War repeatedly ordered that the Agrarian Reserves not take part in politicswith little effect. ${ }^{90}$ In order to weed out would-be caciques, the peasant militia was to be made up of peasants with "revolutionary principles." But in practice, ideological purity was usually equated with loyalty to officials of the Agrarian Bank. ${ }^{91}$ Moreover, there is evidence that the leadership of the Reserves was not composed of average peasants. Parcelarios (yeomen farmers with their own, privately-held small plot of henequen) and even state employees led local units of the Agrarian Reserves. ${ }^{92}$

Most local militia chapters-leaders and rank-and-file members alikewere chosen from local factions already cooperating with the Agrarian Bank. The creation of the Agrarian Militia exacerbated existing divisions between peasants (residents of towns and villages) and peons (landless rural proletarians who dwelled on haciendas) in many municipalities. Peasants made up the vast majority of recipients of land grants and the Agrarian Reserve, while the peons were generally excluded from both. In regional political conflicts, peasant ejidatarios tended to be supported by officials of the federal Agrarian Bank, while peons were generally organized into peon syndicates backed by the state government. ${ }^{93}$ In some cases, the Agrarian Militia program did serve the original mission envisioned for them by Cárdenas of empowering peasants against landlords. In Dzidzantún, armed peasants defended their rights to land and access to rasping machinery against landlords. ${ }^{94}$ In several other cases, peasants armed by the federal

\footnotetext{
${ }^{89}$ Benigno Pinzón to Governor Palomo Valencia 12 October 1936, AGEY PE 1018; Diario del Sureste 23 January 1937.

${ }^{90}$ Diario de Yucatán, 3 April 1937.

${ }^{91}$ See Luciano Kú et al. to President Cárdenas 9 October 1938, AGN DGG 2.311 vol. 85 exp. 28.

${ }^{92}$ For instance, Exaltación Cauich of Chablekal, sergeant in the First Battalion, was a leader of the state association of small- and medium-sized producers of henequen. Víctor Baquedano, a lieutenant in the First Battalion, was an employee of the federal Agrarian Bank. Diario del Sureste 26 February, 28 April 1938.

${ }^{93}$ Luciano Kú et al. to President Cárdenas 9 October 1938, AGN DGG 2.311M vol. 85 exp. 28; Rafael Molina to President 11 August 1937, AGEY PE 1068 SG 1; Chief of Staff to Attorney General 20 September 1937, AGEY PE 1031 SG 2; Tranquilino Marín M. to President 9 February 1937, AGN DGG 2.311M vol. 83 exp. 13; Diario del Sureste 17 March 1937.

94 Villanueva Mukul, Henequén ý haciendas, pp. 52-53.
} 
government occupied land after their claims had been frustrated by endless bureaucratic delays, the hostility of Governor Palomo Valencia's administration, and legal stays by the landowners. ${ }^{95}$

It was more often the case that the peasant militias' actions deviated from their mission of protecting ejidos and thwarting reactionary hacendados. The combination of alcohol and access to firearms through the militia program at times led to violence against a wide variety of targets. On December 22, 1936, in the town of Seyé, an employee of the Agrarian Bank and a sergeant in the Agrarian Militia drank, shot out the lights of the town hall, and killed a dog. ${ }^{96}$ More frequently, however, peasant-soldiers in Yucatán turned their rifles not against dogs or their class enemies but against factional rivals in local political disputes, often the peons. ${ }^{97}$ Indeed, the Agrarian Militia frequently aimed at evening old political scores, and all too often the victims were peons or peasants from rival factions.

In Mococha, a larger village in the center of the henequen zone, peasant politicians and reputed "bosses of the ejido" regained control of town hall and the ejido by using the peasant militia to intimidate local opponents. Ejidatarios of the Agrarian Reserve who resented the town council's opposition to the federal Agrarian Bank and complained of a rigged election threatened local authorities with their newly-received rifles, apparently encouraged by a federal army officer. ${ }^{98}$ In nearby Cacalchen and Tepakan, similar armed confrontation occurred between peasant members of the Agrarian Reserve and the town councils supported by peons and the state government. ${ }^{99}$

Events in another henequen town, Homún, exemplified the endemic conflicts between peon and peasant factions that the Agrarian Reserves were often drawn into. Peons who controlled the town council of Homún with the aid of Governor Palomo Valencia were bitterly opposed by peasants who controlled a national ejido with the support of federal agrarian engineers. ${ }^{100}$ The formation of a squad of eleven Agrarian Reserves under the leadership of Sergeant Maximiliano Pech, reputedly an ejidal cacique, gave the pro-

95 See numerous correspondence AGEY PE 1019 SG 1.

${ }^{96}$ Mayor of Seyé to Public Ministry 22 December 1936, AGEY PE 1068 Sec. Hoctún.

${ }^{97}$ Diario de Yucatán, 2 April 1937.

98 Diario de Yucatán, 18 November 1936.

99 Mayor Cirilio Ac Aké to governor 4 February 1937, Police Chief to governor, 12 March 1937, AGEY PE 1031 SG 2; Diario de Yucatán, 15 June 1937.

${ }^{100}$ Diario de Yucatán, 5, 9 May 1937; Rufino Lavin to Governor 30 March 1936, AGEY PE 1018 Sec. CLA. 
federal peasant faction a decisive edge over the peons. ${ }^{101}$ Pech's faction had long petitioned the governor to have the town council of Homún replaced with an appointed council more responsive to their interests. Higher taxes and the firing of peasants from local haciendas on the orders of the mayor added to their grievances. Pech and his peasant backers took matters into their own hands on the night of April 12, 1937. His squad stormed town hall, jailed a municipal policeman, and named a town council of its own. ${ }^{102}$ Although the state congress refused to recognize the coup, Pech's band allegedly withdrew over 200 pesos from the municipal treasury before abandoning town hall. Their local foes were even more outraged when federal qfficials blocked criminal charges against them. ${ }^{103}$

Such intra-communal feuding involving the Agrarian Militia broke out in other states as well. The violence forced Cárdenas to plan to disband the Agrarian Reserves across Mexico in August 1937-ironically about the same time he was threatening the hacendados with them in Yucatán. ${ }^{104}$ Less than a year after calling for their foundation, Cárdenas announced the dissolution of the Agrarian Militia on grounds that the national army and "class solidarity" gave peasants all the protection they needed. ${ }^{105}$ Several months after the end of the Crusade of the Mayab, the federal and state governments ordered the demobilization of the peasant militia. Judging by the reaction of the platoon of Dzidzantún, the peasant militia surrendered their arms only grudgingly, and many units managed to keep their guns for several years more. ${ }^{106}$ Perhaps the militia had already served its purpose of intimidating hacendados. In any case, the experiment with peasant militias in Yucatán suggests that this vaunted "class solidarity" still had yet to emerge in many rural communities.

${ }^{101}$ José Benignos to governor 8 June 1937, AGEY PE 1044 SG 1.

102 Francisco Millán to governor 13 April 1937, AGEY PE 1044 SG 1.

${ }^{103}$ Diario del Sureste, 28 April 1937; Diario de Yucatan, 15, 16 April 1937, 5 May 1937; Pedro Pool et al. to Federal Commander of the Zone 24 May 1937, AGEY PE 1044 SG 1.

${ }^{104}$ Cárdenas' inability to control the Agrarian Militia provides an interesting comparison with Porfirio Díaz experience with the Rurales (rural constabulary), who despite their reputation were often prone to unrestrained violence. See Paul J. Vanderwood, Disorder and Progress: Bandits, Police, and Mexican Development (Lincoln: University of Nebraska Press, 1981).

${ }^{105}$ Diario del Sureste 22 August 1937. Although some platoons did turn in their weapons, others still had their guns as late as 1939. See Villanueva Mukul. Henequén y haciendas, pp. 62-63. The peasant militias were not totally disbanded until the term of Cárdenas' successor, Avila Camacho. Craig, The First Agraristas, pp. 130-131. The involvement of agrarian militias in factional disputes was not confined to Yucatán. In Pisaflores in the central state of Hidalgo, agrarian militias armed with rifles shipped from Mexico City participated on both sides of a factional dispute. Frans J. Schreyer, The Rancheros of Pisaflores: The History of a Peasant Bourgeoisie in Twentieth-Century Mexico (Toronto: University of Toronto Press, 1980), pp. 90-91.

106 Villanueva Mukul, Henequén y hacienda, pp. 62-63. 
Cárdenas scaled back his government's commitment to agrarian reform even further shortly after the Crusade. In 1938 he withdrew the Agrarian Bank from the Henequen Zone, and gave the state government control over the economically-struggling ejidos. Certain hacendados influenced the state's agrarian reform agency (the "Great Ejido") in the later 1930s, and most regained possession of the processing equipment which in turn allowed them to retain much of the economic surplus produced by the ejidos. ${ }^{107} \mathrm{By}$ the end of Cárdenas' term in 1940, both the militia and the president's threatened second caste war had passed into history, leaving no apparent trace in the state's official account of agrarian reform.

\section{Cárdenas in Search of the Maya}

The success of Cárdenas' indigenismo hinged on creating a cohesive ethnic and class identity among rural peasants of Yucatán, a task seemingly made easier by the preservation in the Yucatecan countryside of the Maya language and other cultural traits centuries after the Spanish conquest. Yet despite state and federal efforts, Cárdenas discovered that mobilization along class and ethnic lines proved extremely difficult. Yucatecan peasants who were of Maya descent, spoke Maya, and lived in a way that seemed to outsiders as clearly "Maya" did not readily identify themselves as "Maya." Extant documents from the 1930s written by Maya-speaking peasant authors exhibit little evidence of a Maya identity or consciousness. In dealings with non-peasants, individuals and communities identified themselves as poor campesinos (peasants), ejidatarios, or members of political parties (Socialist), but only rarely did peasants represent themselves as Maya. ${ }^{108}$

Although there is certainly a danger in "up-streaming" results of ethnographies from later periods, Irwin Press's study of the Yucatecan community of Pustunich in 1963-64 over a quarter century after the Cardenista Crusade-confirms the lack of an Indian or Maya identity among a community classified (by outsiders) as Maya. Press records the persistence of Maya language and traditional dress in Pustunich, yet notes that few people identified themselves as indios or Indians. When he asked peasants to describe Indians, Maya-speaking Yucatecans named the Caste War rebels (the

\footnotetext{
107 Benítez 175; Marie Lapointe, "El estado Mexicano y las elites del henequén en Yucatán" Gaceta Universitaria 12 (1991) 12, 16; Eric Villanueva Mukul, El henequén en Yucatón: Industria, mercado y campesinos (Mérida: Maldonado, 1990), p. 109.

${ }^{108}$ From letters from Yucatecan peasants to state officials from AGEY and AGN LC.
} 
"real" or "legitimate" Maya) or the Sioux in imported North American movies, not themselves. 109

Still, the troubling question remains: why did rural folk speaking Maya and maintaining Maya folkways not respond to an invitation to the state to mobilize along ethnic lines? The lack of popular response to indigenist programs is even more puzzling considering that the state offered positive incentives in the form of land and educational opportunities to individuals (or communities) which identified themselves as Maya or Indians. Part of the answer may lie in the very nature of the various state projects trumpeting Mayanism/indigenismo. Franco Savarino's micro-historical examination of Abalá, a small town south of Mérida, found little evidence that the Maya peasantry participated in the indigenous revival that Felipe Carrillo Puerto's administration sought to foster. Savarino argues that the pre-Hispanic Maya culture which the state attempted to recreate did not correspond with their "neomaya" peasant identity; peasants perceived state-sponsored Mayanism as too "artificial" and "intellectual." 110 As one historian has noted, it seems questionable whether most peasants saw Maya ruins as more than a source of stone for the walls of their huts. 11 Carrillo Puerto's Mayan indigenismo at least had spoken to the Maya in their own language-would not the Cardenista indigenismo which had to be translated into Maya have seemed even more abstract and artificial to Yucatecan campesinos?

It would be hasty to equate a lack of popular response to state-sponsored indigenismo with the total absence of ethnic consciousness or Maya identity among the Yucatecan peasantry. There is evidence that some indigenous peoples identified themselves as Maya. We have a tantalizing hint of such Maya consciousness in the memoirs of Eustaquio Ceme as dictated to North American anthropologist Robert Redfield and his Mexican collaborator Alfonso Villas Rojas, years after the events of the 1920s and 1930s. Ceme, a Socialist leader of the small eastern pueblo of Chan Kom, wrote that the "Maya race" fought in the Revolution yet had been denied its benefits. ${ }^{112}$ Unfortunately for Cárdenas, such ethnic consciousness seemed both rare and difficult for outsiders to reach through political projects.

Of course, the state would not necessarily have to awaken indigenous peoples' consciousness from above; ethnic identity could emerge from be-

\footnotetext{
${ }^{109}$ Irwin Press, Tradition and Adaptation: Life in a Modern Yucatan Maya Village (Westport: Greenwood Press, 1975), pp. 18, 22, 72.

110 Savarino.

111 The author is indebted to Terry Rugeley for this observation.

112 Robert Redfield and Alfonso. Villa Rojas, Chan Kom: A Maya Village (Chicago: University of Chicago Press, 1957), p. 229. The author would like to thank Paul Sullivan for bringing this passage to his attention.
} 
low. Ethnohistorian Franz Schreyer has documented how indigenous Nahua-speaking peasants in central Mexico had a strong common identity and unity that mestizo peasants lacked because of a "strong correlation between class membership and ethnic affiliation."' 113 Certainly, in Yucatán there was a similar correlation between poverty and Mayaness. Unlike the Nahua communities of Central Mexico studied by Schreyer, however, communal unity had largely broken down in most of Yucatán due to the expansion of henequen plantations in the last decades of the nineteenth century. Moreover, the closed community which guarded indigenous identity in much of Mexico-including the Maya of the highlands of Chiapas-was probably not present in colonial times in Yucatán. ${ }^{114}$ It seems likely that in most of northern and western Yucatán, Maya identity - even if it had been present in the colonial period-had largely disappeared in the social dislocation caused by the Caste War and the spread of the plantation economy. Without strong communities to nurture it, ethnic identity could not spring up from the grassroots.

The creation (or recreation) of a Maya identity was further hindered because the division between the descendants of the Maya and Yucatecans of European heritage known as catrines (city slickers), ladinos, or vecinos was far from clear-cut. ${ }^{115}$ Cardenista indigenismo could not address the complex and at times fluid nature of ethnic divisions in Yucatán. Mayaness was determined not only by physical appearance, but language and other mutable markers such as dress. Aspects of Mayaness, most importantly the Maya language, were often appropriated by upper-class and middle-class whites and mestizos; Yucatecan hacendados and their overseers, schoolteachers, and priests knew Maya to a much greater extent than middle- and upper-class whites spoke indigenous languages in other regions of Mexico. Cardenista indigenismo never could clarify the blurry lines between the "Maya" and the "whites."

The artificiality of state-sponsored indigenous projects, weak communal identity, and permeable ethnic boundaries all combined to make collective action along racial lines extremely difficult. Cárdenas discovered this when he attempted to raise the possibility of a second caste war. Maya-speaking

${ }^{113}$ Franz J. Schreyer "Ethnic Identity and Land Tenure Disputes in Modern Mexico," in John E. Kicza, ed., The Indian in Latin American History: Resistance, Resilience, and Acculturation (Wilmington, Delaware: Jaguar Books on Latin America, Number 1, Scholarly Resources, 1994), pp. 206-207.

${ }^{114}$ Robert Patch, Maya and Spaniard in Yucatan, 1648-1812 (Stanford: Stanford University Press, 1995), p. 65. Press; Traditions and Adaptation, p. 16, contrasted Yucatán with the rest of southern Mexico in the 1960 s, and concluded that Yucatecan villages lacked the strong social cohesion present in other parts of southern Mexico.

115 For a more detailed analysis of the pitfalls of "racial" classification, see Knight, "Racism," pp. 73-75. 
peasants armed by the federal government frequently departed from the Cardenista script, which cast them as champions of their race eager to confront the white landowners. Peasants took the rifles and improvised. More often than not, they turned the guns on other peasants because of factional feuds over local political spoils. In this respect at least it resembled the original Caste War, not as imagined by Cárdenas as a war pitting the poor Maya peasants against white landowners, but as a socially and ethnically complex event that erupted when the white elites armed Yucatecan peasants to use as pawns in their own struggles yet proved unable to control them. ${ }^{116}$

- The Cardenistas, like revolutionary politicians (and even some conservative intellectuals) before them, put forward their own interpretation of the Caste War, and went much farther than native Yucatecan politicos in raising the possibility of a second ethnic conflict. The Cardenista Crusade of the Mayab may have cowed peninsular landowners, but it ultimately failed to transform Yucatecan society. Although agrarian reform broke up many henequen haciendas, it failed to create functional collective farms. Once armed, the peasant militia turned their rifles on factional rivals, not class enemies. Cardenista indigenist, class-based strategy could not mobilize Maya peasants, not only because of the shortcomings of federal agrarian reform, but also because the nation-state's conception of "Indian" did not resonate among the Maya-speaking peasantry.

The Agrarian Militia's refusal to refight the Caste War underscored the distance between Cárdenas' conception of the Maya-speaking peasantry of Yucatán as an indigenous proletariat, and the reality of rural society. Once armed, peasants displayed little of the class solidarity and ethnic cohesion anticipated by Cárdenas. Despite the persistence of the Maya language, dress, and other cultural features, the rural poor in Yucatán lacked a single, unifying indigenous identity which the expanding national state could tap. Definitions of Mayaness were not absolute or universal, and resisted easy incorporation into the Cardenista project. The local boss continued to command much more loyalty among the peasants than did the abstract identities of class and ethnicity developed in the rhetoric and ritual of the Crusade of the Mayab. Cárdenas armed Maya-speaking peasants and raised the possibility of a Second Caste War, but in the final analysis the Maya militia and the specter of a Second Caste War amounted to a bluff, not a trump.

Eastern Illinois University

Ben W. Fallaw Charleston, Illinois

${ }^{116}$ Wells and Joseph describe a similar situation in Yucatán during the tumultuous 1911-1913 period. 